\title{
Analysis of Drainage Capacity and Rehabilitation Subjected to Rainfall and Reverse Flow of Marengan River as a Main Drain in Sumenep City, Indonesia
}

\author{
Evi Nur Cahya ${ }^{1}$, Ussy Andawayanti ${ }^{1}$, Eva Resmani ${ }^{2}$ \\ ${ }^{1}$ Water Resources Engineering Department, Universitas Brawijaya, Malang, 65145, \\ Indonesia \\ ${ }^{2}$ Office of Public Work, Water Resources Departement, Sumenep Residence, \\ Indonesia \\ evi_nc@ub.ac.id
}

Received 20-07-2018; revised 23-08-2018; accepted 27-09-2018

\begin{abstract}
Land use changing in Sumenep city in recent years has caused runoff in several locations. Therefore, rehabilitations of existing channel to suit the surface runoff are needed. This paper presents capacity determination of existing drainage channels subjected to rainfall with 5-year flood discharge plan and consideration of sea tides effect to Marengan River which crossed Sumenep city. The proposed flood control methods in Sumenep city area was also discussed. The catchment of specified rural area was modelled using SWMM instrument to compare channel conditions before and after rehabilitation. Channel size and height of water level in channel due to rainfall together with the effect of backwater occurred in Marengan River caused by the sea tides was observed during the time. From the analysis, it was found that most of existing secondary drainage channels are uncapable to accommodate rainfall with 5-year flood discharge plan. From the available eight secondary drainage channels outlets, the last three outlets were subjected to reverse flows effect in Marengan River due to sea tides. In order to reduce the occurance of surface runoff inundation, secondary drainage channel rehabilitation was planned at each outlet, and these proven capable to accommodate rainwater runoff and reverse flow as well.
\end{abstract}

Keywords: runoff, drainage channels capacity, SWMM, reverse flow

\section{Introduction}

Some of the land designated as green land has partially transformed into residential land as a result of urban development. A study of infiltration in the residential land have almost never conducted. The existing channel dimensions cannot accommodate surface runoff; therefore, it disrupts the drainage system [7].

The problems in the study area is the occurrence of surface runoff due to changes in land conversion from green land to residential land in recent years, causing some existing drainage channels to be unable to channel the runoff. Marengan River, as the main drain in Sumenep City, end up at the sea, as Sumenep City located at the north of Java Sea. This caused another problem as Marengan River is affected by backwater caused by the sea tides. 
The objective of this study was to determine the capacity of existing drainage channels to rainfall with a 5-year return period and determine the flood control that can be carried out in the study area.

\section{Material and Methods}

The data required in this study are: location map, topographic map, land use map, drainage channel network scheme, existing drainage channel data, rainfall data, population data and geometric data of Marengan River as an analysis on final disposal.

The study area in Sumenep City sub-district is a strategic area because it is the capital of Sumenep Regency (Figure 1).

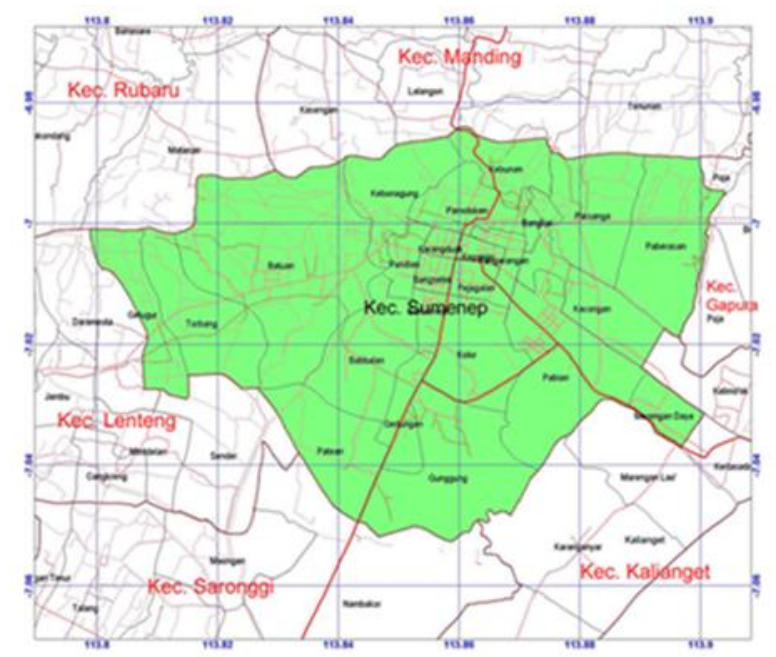

Figure 1. Study area of Kecamatan Sumenep

There are three rainfall stations around the study location, namely Kebonagung, Parsanga and Pengairan Stations. The 10-year daily rainfall data is from 2006 to 2015. The location of the three rain stations is seen in Figure 2.

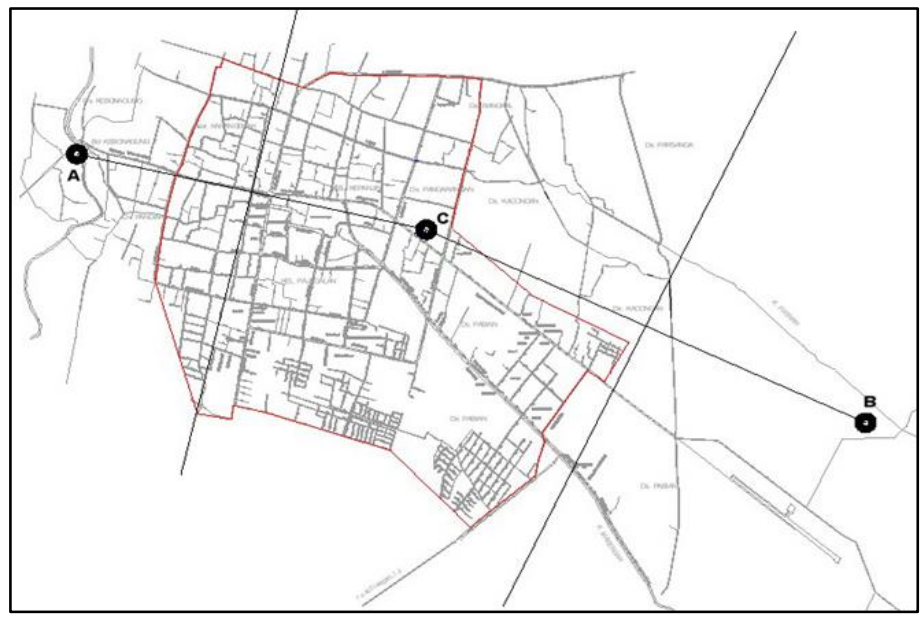

Figure 2. Location of the rain station in the District of Sumenep City

Stages of Analysis

Broadly speaking, the stages of analysis in this study consist of: hydrological analysis, analysis of dirty water discharge, plan discharge analysis based on a 5-year return period using the SWMM (Strorm 
Water Management Model) program, calibrating the model using the Root Mean Square Errors (RMSE) method and final discharge analysis.

In this study the design rain was chosen Log Pearson III method [5], with the consideration that this method is more flexible and can be used for all data distribution.

$$
\log x=\overline{\log x_{i}}+G . S d
$$

where :

$\mathrm{x}=$ Rainfall design with certain return period

$\mathrm{x}_{\mathrm{i}}=$ maximum area rainfall as much as $\mathrm{X}_{1}, \mathrm{X}_{2}, \mathrm{X}_{3}, \ldots ., \mathrm{X}_{\mathrm{n}}$

$\mathrm{G}=$ is a constant obtained from the Pearson Type III Log table from the relationship between Cs and return period $(\mathrm{T})$.

$\mathrm{Sd}=$ standard deviation

Chi-Square Test and Smirnov-Kolmogorov Test are used to determine whether the distribution equation chosen can represent the statistical distribution of sample data to be analyzed. Equation $\mathrm{X}^{2}$ counts on Chi Square test with formula [6]:

$$
X^{2}=\sum_{i=1}^{n} \frac{O j-E j}{E j}
$$

$\mathrm{X}^{2}$ critical values are obtained through the Chi-Square table. If $\mathrm{X}^{2}$ counts $<\mathrm{X}^{2}$ critical then the analysis of rainfall distribution observations is in accordance with the theoretical model.

The Smirnov-Kolmogorov test was conducted to determine the horizontal deviation scattered in the theoretical and empirical distribution. This horizontal deviation is expressed by $\Delta_{\max }<\Delta \mathrm{cr}$ for a certain degree of reality, it can be concluded that the distribution hypothesis can be accepted. $\Delta_{\max }$ equation in the Smirnov test - Kolmogorov [8]:

$$
\Delta \max =|\mathrm{Pe}-\mathrm{Pt}|
$$

$\Delta \max =$ maximum difference between empirical and theoretical opportunities

$\mathrm{Pe}=$ empirical opportunity

$\mathrm{Pt}=$ theoretical opportunity

$\Delta \mathrm{cr}=$ critical deviation (from table)

The selected frequency distribution can be accepted if $\Delta_{\max }<\Delta \mathrm{cr}$ and it and rejected if $\Delta_{\max }>\Delta \mathrm{cr}$.

Duration and Frequency Intensity Analysis (IDF) was carried out to estimate peak discharge in small catchment areas [9], using the Mononobe formula as follows:

$$
I=\frac{R_{24}}{24}\left[\frac{24}{t_{c}}\right]^{2 / 3}
$$

where:

$\mathrm{I}=$ rain intensity during concentration time ( $\mathrm{mm} / \mathrm{hour})$

$\mathrm{R}_{24}=$ daily maximum rainfall

Wastewater discharge is a discharge that comes from household waste, buildings, agencies and so on. The amount is affected by the number of population and the average water needs of the population. As for the average population water requirement is 150 liters/person/day. While the discharge of dirty water 
that must be discharged in the channel is $70 \%$ of the need for clean water so the amount of wastewater is [4]: $150 \times 70 \%=105$ liters/person/day $=0.00121 \mathrm{liters} / \mathrm{sec} / \mathrm{person}$.

For a population of $(\mathrm{Pn})$, the dirty water that is disposed of every $\mathrm{km}^{2}$ can be calculated as follows:

$$
\mathrm{Qak}=(\mathrm{Pn} . \mathrm{q}) / \mathrm{A}
$$

which:

Qak = Wastewater discharge $\left(\right.$ litre $\left./ \mathrm{sec} / \mathrm{km}^{2}\right)$

Pn = total population (person)

$\mathrm{q}=$ total wastewater (litre/sec/person)

$\mathrm{A}=\operatorname{area}\left(\mathrm{km}^{2}\right)$

To calculate the design flood discharge the SWMM software was developed by EPA (Environmental Protection Agency - USA) [10], since 1971. SWMM is classified as a dynamic flow rain model that is used for simulation with a continuous time span or momentary flood events. This model is most widely developed to simulate hydrological and hydraulic processes in urban areas. By using SWMM, the conditions that occur in the field can be modelled by entering the parameters recorded in the actual conditions.

Final discharge analysis is carried out to determine the effect of backwater from the river to the channel. By comparing the water level in rivers and channels. If the water level in the river is higher than the water level in the channel, then the calculation of the effect of back water on the channel is carried out. However, if the channel water level is higher than the river water level, it is not necessary to calculate the effect of back water. This analysis uses the Direct Step Method using equations [3]:

$$
\Delta x=\frac{\left(y_{2}+\frac{V_{2}^{2}}{2 g}\right)-\left(y_{1}+\frac{V_{1}^{2}}{2 g}\right)}{I_{o}-I_{f}}
$$

In general, the analysis stages of this research consist of: hydrological analysis, dirty water discharge analysis, discharge plan analysis based on 5 year return period using SWMM (Storm Water Management Model) program, model calibration using Root Mean Square Errors (RMSE), and final disposal analysis .

\section{Result and Discussion}

To supplement the missing or damaged data, data from other stations that have complete data and the location of the station closest to the station with missing data. From the calculation results of the maximum rainfall data of $64 \mathrm{~mm}$ Irrigation rain station in 2007 and total rainfall data of $1,274 \mathrm{~mm}$ Irrigation station in 2007.

To ensure that the available rain data is feasible to be used in subsequent analysis, the existing data is tested statistically. The statistical analysis includes: consistency test, trend absence test, stationary test and persistence test.

From the result of consistency test, it can be concluded that the rain data on the three rain gauge stations is consistent which means that in the area of influence of the station there is no environmental change and there is no change in the way of measuring during the recording of the data.

In the absence of trend test, rain data on each station is tested by the absence of trend. The periodic series of two data series (Rt dab Tt) is independent on 5\% confidence degree. And dk $=10-2=8$, then obtained tc value equal to 1.860 . From the calculation results obtained thitung for each rain station Kebonagung, Parsanga, and Pengairan for: -0.189 ; 0.688; and 0.363, then tcal < tc. In addition to the ttest calculations, the absence of trends can also be determined by describing the periodic series in the graph (Figure 3 to 5). Thus it can be concluded that rainfall data in the period 2006 - 2015 recorded on the three stations have no tendency toward one direction, the direction of up or down (trend). 
In this stationary test the data is divided into two groups, so that the rainfall data at the study site is divided into Group I for the period 2006 - 2010 and II for the yearly rain period 2011 - 2015.

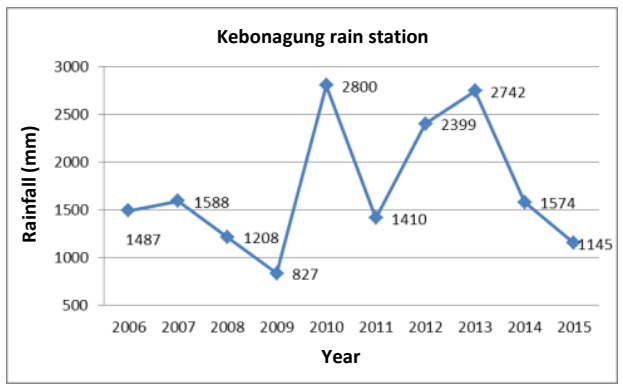

Figure 3. The periodic series of rainfall data of Kebonagung station

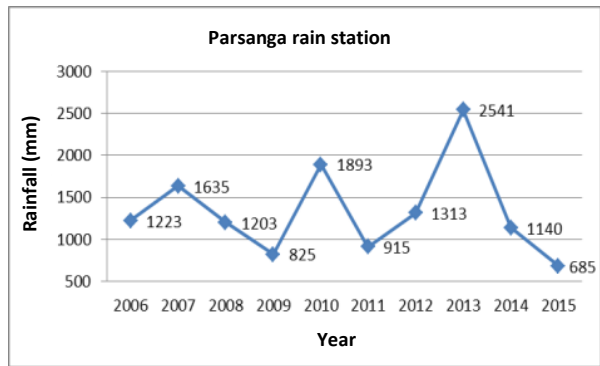

Figure 4. The periodic series of rainfall data of Parsanga station

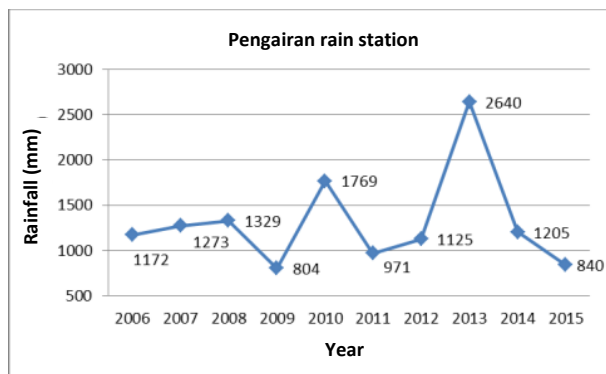

Figure 5. The periodic series of rainfall data of Pengairan station

Test of variant stability

Obtained $\mathrm{F}$ for each rainfall data station Kebonagung, Parsanga and Watering is 1.182; 0.330; and 0.224 , while the value of $F_{\text {critical }}=6.39$, then $F_{\text {critical }}>F_{\text {cal. }}$. So it is concluded that the rain data on the station based on the stability test of variance is stationary or homogeneous.

The stability test is average

Obtained $\sigma$ and $\mathrm{t}$ for each rainfall data of Kebonagung, Parsanga and Watering stations were 797.08 and (-0.54); 659.13 and $0.09 ; 639.72$ and $(-0.21)$. While the $t_{\text {critical }}$ value for $\mathrm{dk}=8$ obtained value 1.860 then $t_{\text {critical }}>t_{\text {cal. }}$. So it is concluded that the rain data is stationary.

In persistence test, $\mathrm{KS}$ and $\mathrm{t}$ values are obtained. With $\mathrm{dk}=8$ then $\mathrm{t}_{\text {critical }}=1.86$. From result of persistence test analysis where $t_{\text {critical }}$ value $>t_{\text {cal }}$ hence can be concluded that available rain data is independent or does not show existence persistence. Or it can be said that the data is a random data.

The average maximum rainfall for the area is obtained by using data from 2 (two) influential rain gauge stations, namely: Kebonagung Station and Pengairan Station. Observation period of rainfall data used for 10 (ten) years from 2006 until 2015. The calculation of the average rainfall is done by using arithmetic method. From the calculation obtained the highest rainfall is equal to $131 \mathrm{~mm}$, lowest $57 \mathrm{~mm}$ 
and average of $82 \mathrm{~mm}$. From the calculation stage of rainfall design Log Pearson Type III, obtained rainfall design return period of 5 years of $97.84 \mathrm{~mm}$.

By using Mononabe equations of heavy rain with short duration can be obtained. Count is done with duration up to 300 minutes (5 hours). The 5-year rain depth with a duration of 1-5 hours becomes the rain input parameter in the SWMM simulation (Table 1).

Table 1. Rainfall Design

\begin{tabular}{cc}
\hline $\begin{array}{c}\text { Duration } \\
\text { (minutes) }\end{array}$ & $\begin{array}{c}\text { Return Period } \\
5 \text { years }\end{array}$ \\
\hline 60 & 33,92 \\
120 & 21,37 \\
180 & 16,31 \\
240 & 13,46 \\
300 & 11,60 \\
\hline
\end{tabular}

Based on the sub map of Marengan River Basin, the existing drainage system is divided into 8 outlet points. The outlet points are sorted by the highest elevation position measured from the upstream of the Marengan River. Here is the description:

1. Outlet 1. This secondary drainage network passes Diponegoro road - General Sudirman - Ahmad Yani

2. Outlet 2. This secondary drainage network passes Diponegoro road - General Sudirman - Ahmad Yani

3. Outlet 3. This secondary drainage network passes through KH. Sajad - Dr. Wahidin.

4. Outlet 4 . This secondary drainage network passes Dr. Cipto.

5. Outlet 5. This secondary drainage network passes through KH. Mansyur - Raung, then from Urip Sumoharjo Street (PLN intersection to the east).

6. Outlet 6. This secondary drainage network passes the road Wahid Hasyim - Anom Sumenep Market - Perum Bumi Sumekar - Perum Satelit.

7. Outlet 7. Placed on the street Kalimook - Marengan Daya.

8. Outlet 8. Placed in Marengan Laok Village.

As for some input data required by SWMM include:

Input of catchment data (Subcatchment)

Here is the data input used to analyze flood discharge plans for the Sumenep City catchment area.

a. The boundary of sub-catchment area determination is based on the location of the secondary channel adapted to the flow direction and the boundaries of the Marengan Sub-watershed.

b. The impervious percentage (defined as waterproof area) is determined based on Google Earth Pro Image Data on imaging date 02 August 2016.

c. Percentage of land slope is taken based on contour map of Marengan River Basin.

d. Depressed heights are part of the pervious and impervious surfaces in which there are puddles, potentially becoming runoff, expressed in $\mathrm{mm}$ units. The value of puddle height for impermeable and porous areas varied according to field conditions in the field. The high value of the inundation in the impermeable area can be divided into 2 types, namely: $1.27 \mathrm{~mm}$ settlement and 2.54 $\mathrm{mm} / \mathrm{asphalt}$ road. While for the high value of puddles on porous land can be divided into 3 types, namely: $5.8 \mathrm{~mm}$ paddy field, $5.7 \mathrm{~mm}$ of stressed field, and yard area of $2.55 \mathrm{~mm}$

e. Infiltration is a process in which rainwater seeps into the surface of the pervious subcatchment area. SWMM provides three options for modelling infiltration, the Horton equation, the Green - Ampt method, and the curve number method. This analysis uses the Horton equation.

f. Area of catchment area. For sub-catchment area obtained from digital map using AutoCad application.

g. Outlet. It is the name of the node that receives the flow of water in the subcatchment. 
h. The width of the catchment area, taken based on the width of the actual catchment area in the field.

A conduit is a link that drains water from a node to another node in the drainage system in which case it can be either open or closed channels. The channel cross section can be determined through the table provided.

The basic junction elevation is taken based on actual conditions in the field. As for the maximum water depth is taken based on the maximum water level on the channel.

To be able to calculate the dirty water discharge data required population of Sumenep City. Then the population data is projected until 2033. Using the equation 5 the discharge of dirty water in the secondary canal can be calculated. The gross water discharge obtained becomes the input inflow parameter in SWMM.

From the SWMM simulation results, total flood discharge design is obtained. The discharge is an accumulation between the discharge of dirty water and the rain water discharge from upstream to downstream channel.

To measure the accuracy of the forecast result of a model, a Root Mean Square Error (RMSE) calibration is performed. From the calculation result of simulation flow and observation flow on channel C19 ' (outlet 3) obtained RMSE value of 0.139. The value indicates that the parameter values used in the modeling approach the variation of the observed value. By comparing the discharge design and capacity of the existing channel, some channels are not able to accommodate a 5 year redischarge. For that required drainage channel rehabilitation. The strands on each channel serve as the basis for calculating the new dimension. In accordance with Regulation of Minister of Public Works No. 12/PRT/M/2014 on Implementation of Urban Drainage System [1, 2], its drainage facilities are at least $10 \%$ higher than the capacity of the drainage plan. Accordingly, the discharge design obtained is multiplied by 1.1 .

The drainage network in need of rehabilitation includes $1,2,4,5,6$, and 8 outlets. In outlet 2 , besides the dimension change, alternatives of the diversion to the Patrian River are also made. This is able to decrease runoff discharge at outlet 2 from initially of $7.15 \mathrm{~m}^{3} / \mathrm{s}$ to $2.77 \mathrm{~m}^{3} / \mathrm{s}$.

After conducting capacity analysis and channel rehabilitation, the final waste disposal in Marengan River is done. To know the effect of backwater from river to channel by using Direct Stage Method. There are 4 outlets that have effect on backwater, that is outlet 4 , outlet 5 , outlet 6 , and outlet 7 , with long influence of backwater respectively, $317.93 \mathrm{~m}, 677.50 \mathrm{~m}, 507.41 \mathrm{~m}$, and $1523.41 \mathrm{~m}$. The water level at outlet 4 , outlet 5 , outlet 6 , and outlet 7 is affected by the rain with the 5 year recycle and the effect of backwater from the river. So, in the calculation of the new dimension of the channel, the water level due to rain with the 5-year rework period is added with the water level due to the effect of backwater from the river so that 4 outlets affected by the backflow are able to accommodate the rain with the 5-year return period and the effect of backwater from river.

\section{Conclusions}

From the results of calculations on data analysis and discussion in the previous chapter it can be drawn some conclusions, among others as follows:

1. From the calculation results obtained capacity of outlet $1=3.53 \mathrm{~m}^{3} / \mathrm{s}$; outlet $2=2.75 \mathrm{~m}^{3} / \mathrm{s}$; outlet $3=2.52 \mathrm{~m}^{3} / \mathrm{s} ;$ outlet $4=1.21 \mathrm{~m}^{3} / \mathrm{s}$; outlet $5=4.65 \mathrm{~m}^{3} / \mathrm{s} ;$ outlet $6=6.20 \mathrm{~m}^{3} / \mathrm{s} ;$ outlet $7=1.47 \mathrm{~m}^{3} / \mathrm{s}$; outlet $8=0.60 \mathrm{~m}^{3} / \mathrm{s}$; outlet $9=4.49 \mathrm{~m}^{3} / \mathrm{s}$. Only secondary drainage networks of outlets 3 and 7 are capable of accommodating rainfall runoff, while secondary drainage outlets 1, 2, 4, 5, 6 and 8 are not able to accommodate rainfall with 5 year return period discharge plan. This causes the puddle point to occur in several streets. Outlet 7 is influenced by the reverse flow from the Marengan River to the channel causing runoff at the outlet. For that outlet 7 requires channel rehabilitation due to the effect of backwater.

2. To reduce the inundation caused by surface runoff, rehabilitation plan of secondary drainage channel in each outlet is needed. Meanwhile, to reduce the burden on the outlet 2 discharge, then use the alternative transfer of discharge to outlet 9 which empties into the River Patrean. This 
alternative of debit switch is able to decrease runoff discharge at outlet 2 which initially amounted to $7.15 \mathrm{~m}^{3} / \mathrm{s}$ to $2.75 \mathrm{~m}^{3} / \mathrm{s}$. Based on comparison between water level of Marengan River and channel outlet, at outlets 4, 5, and 6 the influence of backwater from Marengan River to channel outlet. While at outlet 7 after the channel rehabilitation, the outlet is no longer influenced by backflow. The planned new channel dimension is not only capable of accommodating rainfall runoff with a 5 year return period, but also able to accommodate debit runoff due to the effect of backwater from the Marengan River.

\section{References}

[1] Anonim 2014. Tata Cara Penyusunan Rencana Induk Sistem Drainase Perkotaan (No. 12/PRT/M/2014) Jakarta : Kementerian Pekerjaan Umum

[2] Badan Standardisasi Nasional. 1994. SNI 03-3424-1994 Tata Cara Perencanaan Drainase Permukaan Jalan. Jakarta: BSN.

[3] Chow, V. T. 1997. Hidrolika Saluran Terbuka (Open Channel Hydraulics), Jakarta: Erlangga.

[4] Soehardjono. 1984. Drainasi. Malang: Fakultas Teknik Universitas Brawijaya.

[5] Soemarto, CD. 1995. Hidrologi Teknik. Jakarta: Erlangga.

[6] Soewarno. 2002. Hidrologi, Aplikasi Metode Statistik Untuk Analisa Data, Jilid I. Bandung: Nova.

[7] Solikin Solikin, Ery Suhartanto, Riyanto Haribowo., 2017. Analisis penanganan genangan pada wilayah kota Banjarmasin. Jurnal Teknik Pengairan 8 (1), 15-25, 2017.

[8] Sri Harto, 1993. Analisis Hidrologi. Jakarta: Gramedia.

[9] Triatmodjo, B. 2006. Hidrologi Terapan. Yogyakarta: Beta Offset Yogyakarta.

[10] United States Environmental Protection Agency. 2010. Storm Water Management Model 5.0 User's Manual. https://www.epa.gov/water-research. Diakses tanggal 03 Agustus 2016. 